\title{
АНТРОПОЛОГИЯ И ЛИТЕРАТУРА
}

\author{
УДК 343.112; 791.221.8 ～DOI: $10.31249 / \mathrm{hoc} / 2021.02 .09$
}

\section{Андреева Г.Н.*}

\section{СУД И ПРАВОСУДИЕ В РОМАНЕ-ФЭНТЕЗИ Дж.Р.Р. МАРТИНА «ПЕСНЬ ЛЬДА И ОГНЯ» ${ }^{1}$}

Аннотащия. В статье анализируются особенности изображения суда и правосудия в романе-фэнтези Джорджа Р.Р. Мартина «Песнь льда и пламени». Дана общая характеристика изображения суда и правосудия, показана роль королевского суда, раскрыты понятия преступления и наказания, значение аллюзий для понимания фантазийного мира, созданного автором. В заключение роман рассматривается как культурно-просветительский проект.

Ключевые слова: Дж. Р.Р. Мартин; «Песнь льда и огня»; романфэнтези; магаэпопея; королевская власть; борьба престолов; роль суда; особенности правосудия; Средневековье; «параллельная реальность»; культурно-просветительский проект.

Получена: 15.02.2021

Принята к печати: 01.03.2021

* Андреева Галина Николаевна - кандидат юридических наук, ведущий научный сотрудник, ИНИОН РАН, Москва, Россия, е-mail: galinaandr@rambler.ru

Andreeva Galina Nikolaevna - PhD in Law, leading researcher of the Institute of Scientific Information in Social Sciences of the Russian Academy of Sciences, Moscow, Russia,e-mail: galinaandr@rambler.ru

${ }^{1}$ Имеется и второй вариант перевода названия романа-фэнтези, более поэтичный «Песнь льда и пламени», в данном случае используется как основное название «Песнь льда и огня», соответствующее использованному в статье опубликованному русскому переводу, в цитируемых публикациях название приводится в том виде, в котором оно дается в данной публикации. 


\section{Andreeva G.N. \\ Trial and justice in J.R.R. Martin's fantasy novel «A Song of Ice and Flame»}

Abstract. The article analyzes the features of the image of court and justice in the fantasy novel by George R.R. Martin "A Song of Ice and Flame». The general characteristic of the image of the court and justice is given, the role of the royal court is shown, the concepts of crime and punishment are revealed, the meaning of allusions for understanding the fantasy world created by the author. In conclusion, the novel is considered as a cultural and educational project.

Keywords: J.R.R. Martin; «A Song of Ice and Flame»; fantasy novel; magaepopeia; royal power; the struggle of thrones; the role of the court; features of justice; the Middle Ages; «parallel reality»; cultural and educational project.

Received: 15.02 .2021

Accepted: 01.03.2021

У Королевы на все был один ответ. «Отрубить ему голову!» - крикнула она, не глядя. «Я сам приведу палача!»-сказал радостно Король и убежал ${ }^{\text {. }}$ Льюис Кэррол. Алиса в стране чудес

[Льюис Кэррол, 2010, с. 119] Железный трон, согласно пословище, ковался в крови и пламени, но стал седалищем правосудия, как только остьл ${ }^{2}$. Мартин Дж.Р.Р. Пламя и кровь. Кровь драконов [Мартин Дж. Р.P., 2018, с. 41]

Роман-фэнтези Дж. Р.Р. Мартина «Песнь льда и огня» и снятый по нему сериал «Игра престолов» не нуждаются в представлении ни сами по себе, ни как объект научного исследования. Они уже сейчас анализируются в многочисленных статьях и монографиях, более того, учеными предпринята попытка математического моделирования причин успеха романа [Глянцев, 2020]. Фантазийный мир Дж. Р.Р. Мар-

\footnotetext{
${ }^{1}$ Льюис Кэррол. Алиса в стране чудес. - М. : Махаон, 2010. - 192 с.

${ }^{2}$ Мартин Джс. Р.Р. Пламя и кровь. Кровь драконов. - М. : АСТ, 2018. - 384 с.
} 
тина разнообразен и многолик во всех смыслах, что позволяет выявлять в романе культурные конфликты [Заботин, 2019, с. 119-122], изучать его культурную составляющую в лингвистическом (дотракийский и валирийский языки и диалекты последнего, способы образования имен героев, новых слов) [Косарев, 2019, с. 12-13; Демочкина, Михеева, Кузнецова, 2020, с. 151-154; Абакумова, 2016, с. 12-14; Кардакова, 2018, с. 90-93], политологическом (особенности трактовки власти и борьбы за власть в романе) [Томилина, 2019, с. 461-465; Штейнман, 2019, с. 28-47], топонимическом [Мкртчан, 2016, с. 127129] и в других аспектах, в том числе правовых, например, в виде оценки содержания романа с точки зрения теории восстановительного правосудия [Rohani, Abootalebi, 2015, p. 58-63]. Анализ темы суда и правосудия в романе-фэнтези позволяет понять правовой аспект параллельной реальности, рожденной фантазией Дж. Р.Р. Мартина.

\section{Общая характеристика особенностей изображения суда и судебной системы в романе-фэнтези «Песнь льда и огня»}

В романе-фэнтези отсутствует сколько-нибудь целостная характеристика суда и правосудия, судебной системы, способов дознания, следствия, состава судов и применяемого ими законодательства. Это позволяет автору показывать право в новых ракурсах, трансформируя его описания в зависимости от ситуации и потребностей развития художественного вымысла. В произведении имеются отдельные фрагментарные сведения, которые, как правило, озвучиваются мимоходом и варьируются в зависимости от персонажа, в связи с которым они сообщаются, причем читатель узнает о них именно потому, что такие сведения необходимы для основных целей повествования: раскрытия картины бытия конкретного героя. Это вполне естественно, поскольку вопросы суда и правосудия не находятся в центре повествования и не составляют какую-то сколько-нибудь определенную сюжетную линию, это скорее сопутствующие моменты, оттеняющие то или иное направление сюжета. По сути роль суда и правосудия в романе состоит в том, чтобы оборвать жизнь какого-то персонажа и / или изменить ход событий в игре престолов, обеспечив возвышение представителей одной из династий и падение другой. Вместе с тем сделанные вскользь, разбросанные по всему произведению замечания являются своего рода кусочками мозаики, позволяющими читателю по мере чтения произведения сложить их вместе и восстановить, по крайней мере, часть общей картины организации и функционирования суда, а 
также получить некоторое представление о суде и правосудии в мире этого романа-фэнтези. Его дополняет одно из немногих более детальных описаний судебных процессов - суд над Тиреоном Ланнистером, который дает достаточно противоречивую и в целом неприглядную картину королевского суда и его роли в борьбе за Железный трон.

Поскольку в Семи королевствах, судя по ироническому описанию в романе торговых магнатов - «солдат пряностей и лордов сыров», ведется довольно активная торговля, иная экономическая деятельность, и в той или иной степени были развиты экономические связи между королевствами, можно предположить, что заключаются сделки, и в случае их невыполнения возникают споры, которые мы определили бы сейчас как цивилистические. При этом, хотя в романе периодически встречаются выражения «старые законы», «законы Дорна» или характеристики вроде «Станнис чтит закон» (в значительной степени мифологизированная, как показывает изучение поведения данного героя), логика разрешения цивилистических споров подверстана в романе под целевые установки соответствующего персонажа.

Так, освободившая рабов и движимая мыслью о том, что для правления «Миэрином нужно завоевать сердца его жителей, какое бы презрение она к ним ни питала» [Мартин, 2019 в, с. 49], Дейенерис рассматривает просьбу знатного миэринца Граздана зо Галара, желающего, чтобы его бывшие рабыни, открывшие лавку, платили ему определенную долю прибыли. Граздан связывает прошение с тем, что в свое время он купил их для обучения у принадлежавшей ему очень искусной, но уже немолодой ткачихи, чтобы они переняли секреты мастерства. После освобождения от рабской зависимости девушки продолжали использовать полученные навыки весьма успешно и продавали свои ткани в открытой ими лавке.

Если применить к этой ситуации современное правопонимание, то решение достаточно очевидно: договор между сторонами о компенсации средств, затраченных на обучение девушек, отсутствует, иск отклоняется, судебные расходы возлагаются на истца (не говоря уже о том, что за содержание в рабском состоянии истец подлежит уголовной ответственности). Именно такое решение приходит в первую очередь современному читателю вместе с простой и незамысловатой эмоцией: «С какой стати ему что-то полагается?» Однако это будет экстраполяцией на фэнтези современных представлений о праве, с которыми Мартин как раз и стремится столкнуть видение и понимание Дейенерис справедливого разрешения данной ситуации. 
Если же оценивать эту, описанную в романе-фэнтези, ситуацию с позиций революционного права переходных эпох (а именно такой она была для жителей Миэрина после отмены у них рабства Дейенерис), используя аллюзию периода Французской революции с еe упразднением феодальных привилегий или периода российской революции 1917 г., сопровождавшейся отменой буржуазного права, то в этих случаях господа были счастливы, когда им удавалось сохранить жизнь, а постановка вопроса о компенсации собственности становилась абсурдной. Но фэнтези живет по своим собственным законам, и решение Дейенерис это ярко показывает. Она задает вопрос об имени той искусной ткачихи, и Граздан затрудняется ответить («Эльза кажется... или Элла. Уже шесть лет как она умерла. У меня, Ваша блистательность, было много рабов...» [Мартин, 2019 в, с. 55]). С этого момента судебное действо обретает сходство с судом царя Соломона. Дейенерис выносит решение, согласно которому девушки Граздану ничем не обязаны, поскольку ремеслу их научила ткачиха, а бывший рабовладелец должен приобрести для девушек новый, самый лучший станок за то, что забыл имя ткачихи. «Соломоново решение» Дейенерис с наказанием Граздана явно опирается на выявленное пренебрежительное и нерачительное отношение Граздана как хозяина к искусной ткачихе. Здесь прямо напрашивается его противопоставление другому литературному персонажу из «Мертвых душ» Н.В. Гоголя - Собакевичу, который своих, тоже отнюдь не живых, крепостных знал по именам и фамилиям, и даже расхваливал их Чичикову, живописуя, что каретник Михеев обладал силой в плечах, какой нет у лошади, и к тому же только рессорные экипажи делал; кирпичник Милушкин мог поставить печь в любом доме; а прекрасный и непьющий сапожник Максим Телятников что «шилом кольнет, то и сапоги». Собакевич был рачительным и ценящим (на свой лад) крепостных, на его фоне Граздан выглядит простым вымогателем у Дейенерис и хозяином, толком не знающим своих рабов. Но здесь притаилась и еще одна культурная аллюзия. Раб по древним представлениям, которые явно воспроизведены в романе, - это, согласно известному латинскому выражению, «instrumentum vocale», т.е. «говорящее орудие». Такой была и ткачиха для Граздана. По сути его фраза о забытом имени, о множестве рабов и шестилетней давности ее смерти является свидетельством именно такого «инструментального» отношения к ней. Судя по всему, оно было нормой предшествующего периода и вполне согласовывалось с действовавшим до отмены рабства законом, поэтому логика решения Дейенерис в этой части явно противоречит предыдущей 
части решения, поскольку и Граздан в таком случае также ничем не обязан искусной ткачихе и ее ученицам. Это противоречие связано с желанием Дейенерис, обременяя бывшего рабовладельца в пользу учениц искусной ткачихи, заставить его проявить уважение к покойной, которого она явно не имела при жизни. Сомнительно, что Граздан это понял, но Дж. Мартину удалось таким образом, перемешивая в данном решении правовые и неправовые аспекты, создать «гремучую смесь» из разных правовых ситуаций и эпох, разных критериев от государственной целесообразности до политики борьбы с рабством и внушения уважения к бывшим рабам, которая понадобилась автору, чтобы показать внешние проявления намерения Дейенерис покончить с рабством. Ее правовое мышление в целом базируется на этом намерении, но Дейенерис проявляет и гибкость, ориентируясь на государственную целесообразность, которая диктует ей необходимость поддержания стабильности в Миэрине. Отсюда и чередование заслушивания претензий и просьб бывших рабов и господ, и применение как права, которое существовало во времена рабства, так и нового права, вытекающего из отмены рабства. Например, когда вольноотпущенник, женившийся на беременной наложнице вельможи из дома Цхаков, требовал оскопить господина за изнасилование, а себе присудить кошель золота (поскольку растит ребенка от вельможи), то золото Дейенерис ему присудила, а вот изнасилование не было признано. Дейенерис решила, что, поскольку наложница в то время была собственностью вельможи, он мог распоряжаться ею так, как хотел. Автор поясняет ход мыслей Дейенерис: «Если кастрировать всех, кто спал со своими рабынями, город будут населять одни евнухи» [Мартин, 2019 в, с. 56].

В эпопее есть и другие указания о рассмотрении гражданскоправовых споров, но они не образуют системы и не являются важной частью романа как не влияющие на борьбу за власть. Роль суда и правосудия при распределении имущества, в том числе и после репрессий против мятежников, явно уступает по значимости уголовнополитической роли суда в перераспределении власти между физическими носителями.

В сфере уголовного судопроизводства, расследования преступлений и определения наказаний роль усмотрения монарха еще выше. Во-первых, все противники данного монарха автоматически записываются в преступники, и, если он до них добирается тем или иным образом, то скорее всего им не сносить головы. Такими размышлениями персонажей о своей возможной участи и конкретными ее примерами 
полны страницы романа-фэнтези. Уголовное судопроизводство в виде решения короля очень близко в этом смысле в романе к самосуду, который конкурирует по частоте описания с собственно судом.

Можно также сделать некоторые общие выводы о видах судебных систем, используемых в мире Дж. Мартина. Так, достаточно очевидно, что дотракийцы руководствуются тем, что сейчас называется обычным правом, соответственно, и их суд осуществляется в соответствии с этим правом. Что же касается «цивилизованных» королевств, то в них, как это свойственно и европейскому феодализму, правосудие осуществляют, с одной стороны, сеньоры, которые в свою очередь могут обратиться к своему сюзерену, с другой стороны, на вершине судебной власти стоит король. В приквеле «Пламя и кровь. Кровь драконов» описывается довольно подробно именно такая, проводившаяся в прошлом Эйегоном Таргариеном политика. Он считался прославленным воином и величайшим завоевателем, поставившим цель примирить Семь королевств под властью Таргариенов, поэтому запретил лордам решать между собой споры мечом и установил порядок, по которому они должны были обращаться за разрешением споров к своему сюзерену, а споры между высшими лордами разрешал король [Мартин, 2018 а, с. 44].

Королем Эйегоном вроде бы была установлена четкая система судебной юрисдикции. Однако на самом деле - это не столько общая схема, сколько «зарисовка», относящаяся только к суду, действовавшему при данном короле, и она не раскрывает полную картину, поскольку наряду с вышеописанным существовал и другой порядок, как бы «пронизывающий» установленную данным королем четкую иерархическую структуру: когда король Эйегон Таргариен путешествовал по стране (а путешествовал он по полгода) и гостил у великих лордов, то помимо охоты, пиров и балов «всюду вершил королевский суд, будь то во дворе замка или на мшистом камне в крестьянском поле. Шесть мейстеров, сопровождавших его, толковали ему местные законы, приводили примеры из истории и записывали вынесенные им приговоры» [Мартин, 2018 a, с. 43]. Судя по всему, хотя прямо об этом не говорится, король выносил приговоры и в отношении простых людей (на это намекает местоположение осуществления суда - «крестьянское поле»). Другое свидетельство этого - эпизод, относящийся к тому же времени и иллюстрирующий заботу королевы Рейерис «о простых людях, в котором она выносит приговор в отношении мужа, забившего жену до смерти за измену» [там же, с. 48]. 
Таким образом, в условиях относительной независимости или противостояния Семи королевств суд в них вершили их правители и сеньоры без вмешательства центральной власти. При повышении степени централизации, сопровождающейся подчинением и усилением зависимости отдельных королевств от центральной власти, как в случае с Эйегоном Таргариеном, верховный глава простирал свою «длань» и на судебные процессы в королевствах, происходило расширение судебных прерогатив центральной власти.

Параллельно королевской судебной системе существуют религиозные суды, которые выносят решения по морально-религиозным нарушениям. Определенные процедуры существуют и в них, во всяком случае на них распространялась до решения короля Томмена возможность судебного поединка. Некоторые сведения об особенностях этих судов мы узнаем, прежде всего, из попыток Воробьев, и прежде всего его Воробейшества, предать суду королеву Маргери и Серсею Ланнистер, причем последняя еще до суда подвергается наказанию в виде позорного шествия. Однако, чтобы точно раскрыть логику религиозных судов и правосудия, апеллирующего к богам, необходимо подробно остановиться на роли религии в романе, что выходит за рамки данной статьи.

По сути, не только полицейско-осведомительной, но и полусанкционированной и полуконкурирующей с королевской судебной властью обладает лорд Варис, с подчиняющейся ему сетью доносителей и шпионов. Именно он, как отмечают исследователи, «служит концепту власти как таковому» [Круглый стол, 2019, с. 240]. Выступая хранителем Семи королевств, он предоставил сам себе право решать судьбы королей, меняя недостойных (как, например, короля Джоффри). Некоторые исследователи роль Вариса противопоставляют роли Мизинца, полагая, что в мире правового хаоса «с одной стороны, Варис стремится к порядку, рассматривая хаос как крах, и демонстрируя кельзеновское отвращение к краху нормативности и стремление к логически закрытой вселенной; лорд Бейлиш, с другой стороны, рассматривает, как известно, хаос как лестницу, которая, кажется, богата неограниченными решениями и исключениями, но на самом деле выходит за рамки шмиттеанского видения и отменяет все элементы порядка, кроме полного стремления к власти» [Körtvélyesi, 2019, p. 24].

И, наконец, квазисудебной властью в определенных границах, по мнению некоторых исследователей [Körtvélyesi, 2019, p. 1-24], наделен и Ночной дозор, «люди, занятые делом» [Круглый стол, 2019, c. 237]. Как отметил Владимир Берхин, «они не борются за власть, они 
не устраивают какие-то свары. У них есть занятие, полезное для всех» [Круглый стол, 2019, с. 238]. Применение аналогий и опора на теории современных авторитетных специалистов в области права позволяет допустить, что у членов Ночного дозора есть возможности и эффективные инструменты для укрепления правопорядка не только в отношении борьбы с одичалыми, ходоками и иными силами, находящимися по ту стороны Стены, но и всеми опасностями, не охватываемыми правом и правосудием Вестероса, что позволяет им осуществлять правосудие не через центральные органы, не через королевский суд, а на месте, децентрализованно. Ночной дозор, и особенно лорд-командующий, вправе принимать решения, восполняющие лакуны в праве, в том числе в отношении распределения власти, если создается глобальная угроза существованию Вестероса [Körtvélyesi, 2019, p. 14-20]. Речь идет, по существу, об использовании в романе хорошо известной американскому праву доктрины так называемых «подразумеваемых» полномочий, т.е. не прямо не предоставленных, но допускаемых в определенных ситуациях и пределах [подробнее о подразумеваемых полномочиях см.: Кучеренко, 2010, с. 55-65].

Особенность описываемого Дж. Мартином фантазийного мира состоит в том, что стабильность государства как такового, королевской власти Семи королевств обеспечивается не за счет четкой правовой системы или официального правосудия, а за счет интерпретаций ключевых задач этой системы лицами, возглавляющими квазисудебные органы - лордом Варисом и лордом-командующим Ночного дозора.

\section{Многоликое правосудие в романе}

Слово «правосудие» (англ. «јustice») в романе возникает достаточно часто, в разных контекстах и далеко не всегда в связи с понятием официального суда, и даже, пожалуй, чаще в противопоставлении ему.

Киван Ланнистер как аксиому или афоризм произносит фразу: «Правосудие - привилегия трона» [Мартин, 2019 б, с. 579]. Он внешне основательно объясняет Тириону Ланнистеру, как именно (несомненно, справедливо) оно будет осуществляться под руководством его отца. Он полагает, что если Тирион невиновен, то он сможет легко оправдаться. В этом эпизоде, с одной стороны, мы видим, что отсутствует возможность отвода судьи в силу его родственных отношений с подсудимым, принцип, введенный в современном мире для предот- 
вращения незаконного оправдания, и, казалось бы, оправдание Тириона неизбежно. Однако, как представляется, Дж. Мартин намеренно играет со стереотипами читателей, вызывая у них когнитивный диссонанс, поскольку для читателей аксиомой современного правосудия является исключение «конфликта интересов», связанного с родственными отношениями между судьей и подсудимым. Кроме того, парадоксальность подхода Дж. Мартина состоит в том, что для Тириона в этой ситуации именно отвод как раз был бы спасением, поскольку отец рад от него избавиться, а суд дает ему такую якобы «легальную» возможность.

«Просвещаемый» Киваном Ланнистером Тирион хорошо знает расстановку интересов в данном органе и справедливо полагает, что суд по отношению к нему никак не будет справедливым. Эту же мысль подтверждает и пришедший к нему в тюрьму один из его судей дорнийский принц Оберин Нимерис Мартелл, афористически заметив мимоходом: «Правосудие по эту сторону гор торжествует нечасто» [Мартин, 2019 б, с. 591]. Эта фраза тоже могла бы стать эпиграфом к данной статье, поскольку, хотя принц имеет в виду конкретно данное королевство и его официальное правосудие, как представляется, его замечание наиболее точно выражает вообще роль официального, особенно королевского правосудия в романе, что определяется его связью с одной из сюжетных линий романа - борьбой за власть, о чем подробнее будет сказано в следующей части статьи.

С другой стороны, в романе присутствует масса персонажей, которые считают, что они могут вершить «правый суд» в соответствии со своими представлениями, пристрастиями и интересами, и такие персонажи составляют гораздо более широкий круг, чем сидящие на троне или уполномоченные королями лица: от родственников лиц, пострадавших от рук представителей правящей династии, до Безликих, от цареубийц до Вариса и т.д.

Суть происходящего при этом одна и та же, в какой бы религиозно-мистической или морально-оправдательной «упаковке» она ни была. Поскольку официальное королевское правосудие нередко носит характер мести, расправы над политическими противниками в борьбе за Железный трон и далеко не всегда следует установленной процедурной форме, причем нарушаются даже достигнутые в ходе судебного разбирательства соглашения о признании в совершении преступления как основании для смягчения наказания преступника (характерный пример - «экспромт» короля Джоффри в виде замены Неду Старку отправки на Стену отсечением головы), то и вынесенное таким су- 
дом наказание не воспринимается в принципе как правосудие и проявление справедливости.

Соответственно, когда персонаж этого романа-фэнтези твердо уверует, что официальное правосудие с помощью законных процедур невозможно, он переходит к самосуду, вершит правосудие так, как понимает, обеспечивая торжество справедливости доступным ему способом. Такое правосудие имеет характер восстановления справедливости («justice»), как его понимают участники процесса, но при этом содержит сильный оттенок мести. Такая интерпретация правосудия в романе, с одной стороны, соответствует стереотипному представлению о дикости Средневековья (в противоположность, например, «цивилизованному» Возрождению), но, с другой стороны, в гораздо большей степени, присуща самой логике инструментальной функции восстановительного правосудия [Rohani, Abootalebi, 2015, p. 58-63] в фантастическом мире, создаваемом пером Дж. Мартина.

\section{Суд и правосудие в контексте борьбы за Железный трон. Королевский суд}

В произведении несколько основных сюжетных линий, в центре одной из них находится борьба за Железный трон. Эта борьба представлена в виде игры престолов, т.е. монархическое начало государства во многом предопределяет взаимоотношения главных героев, организацию власти и политику, взаимоотношения между правящими в Семи королевствах династиями, и именно они в рамках этой линии находятся в центре внимания автора и читателя. Сам автор признавался в интервью, что для него «Песнь льда и огня» прежде всего - история о власти [цит. по: Солдаткина, 2019, с. 196]. Что же касается суда и правосудия, то они оказались на периферии внимания автора и читателя, являясь одним из инструментов монархической власти. Королевский суд (и не только, во многих случаях и суд зависящих от него владетелей) в большинстве описаний в романе прямо подчинен политике того или иного монарха, подкрепляя тот или иной его образ. Король, который стремится установить мир (как правило, уже подчинив своих соседей), проводит политику минимизации репрессий даже в отношении противников, как, например, Эйегон Таргариен, который желал достичь примирения Семи королевств под своей властью, властью Таргариенов. Однако такие почти идиллические картины (на фоне многочисленных гораздо более кровавых) - редкость в романе. Так, уверенный, что он является избранным, Станнис Баратеон легко и 
жестко решает судьбы огромного числа людей по принципу «либо ты преступил закон, и я тебя убью, либо ты преклонил колена, и я тебя помилую» [Круглый стол, 2019, с. 263]. Более того, правосудие должно носить характер устрашения, эту идею автор вложил в уста королевы Серсеи, которая полагает, что олицетворением правосудия является королевский палач и его должны бояться, как и самого правосудия [Мартин, 2018 б, с. 140].

В романе постоянно идет явная и неявная («подковерная») борьба за Железный трон, летят головы, истребляются целые династии, которые могли бы на него претендовать. И в этой борьбе участники руководствуются не законом, а только собственными интересами и поступают в соответствии со своими возможностями и логикой борьбы за искомый приз - власть. По сути, происходящее можно охарактеризовать как вседозволенность верхнего эшелона власти и приближенных к нему, борющихся за власть, где суд просто инструмент власти, но не правосудия. Роман Дж. Мартина можно рассматривать как художественную иллюстрацию наблюдения известного российского историка права И.А. Исаева: «Если в отдельных сферах деятельности выбор средств ограничен некими сдерживающими нормами или укорененными обычаями, так как там существуют определенные правила игры, то в политике, утверждал еще Макиавелли, ничего подобного не существует. Здесь существует молчаливое согласие о том, что дозволены любые средства, здесь господствует абсолютная борьба» [Исаев, 2019, с. 10].

Официальное, строгое и выдержанное правосудие не может быть орудием борьбы за власть. Как только суд и правосудие становятся орудиями такой борьбы, они превращаются в квазисуд и квазиправосудие, вершащиеся от имени государства, официально, и в этом случае в большей мере соответствуют описываемой Т. Гоббсом ситуации «войны всех против всех» применительно к верхнему эшелону власти.

\section{Понятие преступления и других правонарущений}

Когда в настоящее время обращаются к такому сугубо юридическому понятию как правонарушение, то ориентируются на нормы законодательства. В некоторых странах круг источников права включает наряду с законом судебный прецедент и обычай. Есть ли в Вестеросе законы? Из романа мы узнаем, что законы существуют, более того, так называемые старые законы имеют для части жителей такую по- 
вышенную ценность и значимость, что выигрывают в сравнении с ценностью власти. Такой эпизод представлен в «Битве королей». Когда Эйегон Драконовластный уничтожил старый закон и превратил Железные острова в заштатную провинцию, один из лордов поднял восстание: «И не столько ради такого пустяка, как корона, поднял свое восстание лорд Бейлон, сколько для того, чтобы вернуться к старому закону» [Мартин, 2019 а, с. 139-140]. Однако причины предпочтения короне старого закона, за который велась борьба, и его содержание читатель не узнает, поэтому вправе предположить, что дело было не только и не столько в законе, сколько в интересах, затронутых завоевателем. О некоторых старых законах автор может поведать мимоходом, причем для того, чтобы показать несоответствие одного из героев канонам прошлого. Так, Теон Грейджой, которого ребенком забрали в качестве заложника, возвращается к отцу после десятилетнего пребывания у Старков и выслушивает далеко не самые лестные комментарии о себе и Старках, а также напоминание о том, что он не соответствует одному старому закону: «Согласно старому закону, только женщины могли носить украшения, купленные за деньги, воин же снимал их с врагов, убитых его собственной рукой. Это называлось платить железом» [Мартин, 2019 a, с. 151].

Ситуации проявления уважения к закону в мире Дж. Мартина скорее исключение, потому что мы постоянно видим, что в одном случае (когда им выгодно) герои произведения следуют закону, в другом (когда это не в их интересах) игнорируют его.

В романе говорится даже о попытках кодификации права в королевствах Джейехерисом совместно с септоном Бартом, мейстером Бенифером и королевой Алисанной. И здесь читатель встречает обобщенную характеристику системы законодательства Вестероса: «В каждом из королевств Вестероса, какими Эйгон Завоеватель застал их, имелись собственные законы, обычаи и традиции, которые разнились даже в пределах одного государства» [Мартин, 2018 a, с. 231]. При этом основой данного разнообразия была предшествующая феодальная раздробленность: в отдельные периоды на данной территории было до 132 королевств. В связи с попыткой кодификации законодательства автором дается и такая характеристика законов, которая, с одной стороны, открывает возможности для сведения на нет всех попыток кодификации при нарушении единства Семи королевств (а это единство неустойчиво по своей сути в условиях борьбы за Железный трон), с другой стороны, позволяет и далее Дж. Мартину показывать широкую вариативность в отношении суда и правосудия: «Законы 
были столь же изменчивы. Один король был суров, другой милостив, третий во всем следовал Семиконечной звезде, четвертый - древним законам Первых Людей, пятый - своим капризам, шестой судил трезвый так, пьяный эдак. Противоречивых прецедентов со временем накопилось столько, что каждый лорд, имевший право заточать и казнить (а то и не имевший такого права), решал дела своих вассалов по собственному разумению» [Мартин, 2018 a, с. 232]. Хотя попытки унификации права Джейехерисом, видимо, оказали некоторое воздействие, переоценивать их не стоит, что заметно и по стремлению возврата к старым законам и по оговоркам, относящимся, например, к Дорну.

«Вкусовой» подход к пониманию правонарушений власть имущими сказывается в романе и на трактовке понятия преступления, которое крайне размыто. Четкая иерархия преступлений отсутствует. С одной стороны, вроде бы «цареубийство» относится к тягчайшим преступлениям, с другой - цареубийца Джейми Ланнистер полагает, что «убийство своих родичей еще более тяжкий грех в глазах богов и людей, чем цареубийство» [Мартин, 2019 б, с. 553]. В числе других преступлений относительно часто встречаются упоминания о нарушении клятвы (принесенной королю), дезертирстве, воровстве, браконьерстве и изнасиловании. Однако определение тяжести этих преступлений в романе варьируется, причем главным образом в зависимости от степени жестокости или, наоборот, терпимости и гуманности конкретного короля.

\section{Наказание, или Серебряный бич правосудия}

В книге «Танец с драконами. Грезы и пыль» есть эпизод, когда магистр Иллирио рассказывает Тириону о некоем принце, который между балами и пирами «разъезжает по городу в паланкине из слоновой кости и золота. Герольды несут перед ним золотые весы торговли, железный меч войны и серебряный бич правосудия» [Мартин, 2019 в, c. 42]. В этом описании интересна культурная трансформация символов правосудия. Весы, с которыми изображают Фемиду в этом мире, в «параллельном мире» Дж. Мартина превращаются в символ торговли, что справедливо, логичен и выбор материала для этого символа - торговля приносит золото. Символом правосудия становится бич, т.е. символ наказания. Материал, из которого он изготовлен - серебро, может быть выбран автором как случайно, так и намеренно: он используется в магических целях борьбы с нечистой силой, которую 
может убить только серебряная пуля. Если последнее предположение верно, то это символ наказания согласно воле людей и богов, как об этом говорилось в романе в связи с описанием, упомянутым ранее решением королевы Рейенис, вынесенным после совещания с мейстерами и септонами [Мартин, 2018 a, с. 48]. Но символизирует ли на самом деле наказание и правосудие этот образ в романе?

Наказание в данном произведении не связано напрямую с преступлением, поскольку автор все время показывает читателю, что оно может настигнуть как виновных в совершении правонарушения, так и очень часто невиновных. Примером этого может служить один из главных героев - Тирион Ланнистер, которого дважды обвиняли в цареубийстве, причем первый раз он не имел к этому преступлению отношения, и при этом оба раза сумел избежать наказания. Наказание в романе не является неотвратимым в принципе, потому что гибель персонажей обычно не связана с совершенными ими преступлениями, хотя встречаются и примеры неотвратимости наказания, особенно в случае, если у погибших имеются целеустремленные и, по меткому выражению дорнийского принца, «кровожадные» родственники, жаждущие возмездия.

За большинство преступлений (цареубийство, нарушение клятвы верности королю, дезертирство и т.д.) предусматривается смерть, причем, если наказание устанавливается по решению суда, то практикуется повешение, а также отсечение головы. В ситуации дефицита защитников Стены возможна замена смертного приговора отправкой на Стену. В условиях военных действий головы непокорных или восставших вассалов для устрашения не только отсекают, но и выставляют, насаживая на пики, на всеобее обозрение. За изнасилование, помимо обезглавливания и повешения, в романе практикуется кастрация. Причинение вреда невиновному человеку может караться отрезанием ноздрей.

Способы наказания в результате самосуда разнообразны: от отравления (как избавились от короля Джоффри) до сбрасывания с высоты (Бран, леди Лиза). В некоторых случаях встречаются весьма экзотические способы расправы со слишком зарвавшимся феодаломзавоевателем, например, в романе есть эпизод, когда такой персонаж, по имени Тирелл, погибает, дернув шнур, прикрепленный к балдахину кровати в спальне, вызывая девушку для утех. Балдахин раскрывается, и на Тирелла высыпается сотня красных скорпионов [Мартин, 2019 б, c. 590]. 
Понятие справедливого наказания в Семи королевствах в целом сводится к принципу талиона «око за око, зуб за зуб», причем обычно понимаемому в смысле математического равенства. В некоторых случаях мы имеем дело с тщательным «высчитыванием» равного наказания нарушившего закон как критерия справедливости наказания. В эпизоде королевского суда над мужем, забившем жену за измену до смерти, королева Рейерис дотошно выясняет, сколько ударов было нанесено мужем покойной жене, это ей нужно для того, чтобы понять, не был ли нарушен закон. Читатель узнает, что в Вестеросе, за исключением Дорна, действовал закон, согласно которому муж самостоятельно имел право наказывать жену за измену, причем палка для такого наказания не должна была превышать толщину большого пальца [Мартин, 2018 a, c. 48]. В описываемом случае муж выполнил требование о толщине палки, а вот ударов он нанес около ста, по утверждению братьев покойной (сам обвиняемый затруднился ответить). Рейенис посоветовалась с мейстерами и септонами и вынесла решение, что он мог ударить жену не более шести раз (по числу богов Вестероса, исключая несущего смерть). Превышение этого числа на 94 было объявлено преступлением против богов и людей, требующим наказания, и по повелению королевы братья покойной нанесли виновному 94 удара. Таким образом, само по себе убийство изменившей жены рассматривалось королевой, мейстерами и септонами как справедливое наказание, легально осуществляемое не государством, а частными лицами. Вопрос только состоял в правильности способа его осуществления, что является еще одним культурным шоком для современного читателя, которому супружеская измена представляется не преступлением, подлежащим наказанию, а одним из оснований для развода. С юридико-культурологической точки зрения в этом небольшом эпизоде содержится одна из трактовок в романе принципа талиона. Справедливость с точки зрения государства восстановлена, когда превышение ударов при совершении допустимого наказания жены мужем возвращено ему в том же виде. Нельзя не обратить внимание и на то, что наказание исполняется не официальными должностными лицами, а возложено на представителей пострадавшей стороны, это также размывает границы между судом и самосудом.

Другой пример использования принципа талиона читатель узнает из размышлений Дейенерис о том, правильно ли она наказала виновных. И здесь простое соответствие чисел ей порой не кажется удовлетворительным. Так, она подозревает, что действовала недостаточно (для обеспечения необходимой эффективности управления) жестоко, 
казнив в ответ на казни 163 рабов-детей 163 великих господ Миэлина [Мартин, 2019 в, с. 49].

Если реализация правосудия задерживается и королевская власть или противоположная сторона не стремятся к восстановлению справедливости и суду над совершившими преступление, т.е. не демонстрирует готовность привести ситуацию в равновесие, то этот принцип реализуется путем самосуда и мести со значительным «перехлестом», как в случае убийства Кейтелин Старк. Поэтому правосудие (и самосуд), вроде бы базирующиеся на принципе талиона, на самом деле не только не компенсируют ущерб, нанесенный преступником, но и приводят к еще большему ущербу, отмечают исследователи [Rohani, Abootalebi, 2015, p. 63].

\section{Аллюзии в романе-фэнтези}

Исследователи творчества Дж. Мартина обнаружили уже множество культурных ассоциаций и исторических аллюзий в романе «Песнь льда и огня». Наиболее очевидные художественные параллели проводятся с творчеством Толкиена и Ле Гуин [Штейнман, 2019 a, c. 150-154; Круглый стол, 2019, с. 237, 239, 259-260]. Многочисленные исторические параллели обнаруживаются с войной Алой и Белой розы [Фомина, 2016, с. 97-100], европейским Средневековьем [Аванесян, 2019, с. 74-87], культурой кочевых народов (скифов или хазар) [Шляхтин, 2019, с. 119-134] и т.д.

Что же касается суда и правосудия, то они также рождают различные исторические аналогии и аллюзии. В европейской истории, в том числе в истории Великобритании, исследователи находят многочисленные примеры аналогичных или близких к описанным в романе актов правосудия (особенно неправедного): например, казнь отца Ричарда Плантагенета за измену (в романе казнь отца Робба Старка), обвинение Ричарда III в убийстве племянника, которое было ему просто невыгодно (в романе аналогичное обвинение Тириона Ланнистера) [Иванченко, 2017, с. 22-23] и др. Также нет недостатка в примерах того, как с помощью суда сводились счеты на высшем уровне [Праздников, 2011, с. 153-174].

Вместе с тем, если сравнить реальное европейское средневековое правосудие и правосудие у Мартина, то обнаружим, что первое было в определенном отношении более упорядоченным и организованным. Например, часто упоминаемая у Дж. Мартина государственная измена могла быть признана как решением суда, так и парламен- 
том. В 1351 г. состоялось принятие статута «Об измене», четко определившего деяния, которые могут быть к ней отнесены (что, впрочем, не мешало ложным обвинениям). Система судов не существовала статично, как у Дж. Мартина, она развивалась, подвергалась специализации. Так, вопросы борьбы с бунтами и поддержание государственной безопасности («подавление внутренних государственных волнений») были возложены на Суд Звездной палаты, появившийся при Генрихе VII в 1488 г. [подробнее см.: Стрижаков, 2017, с. 39].

Реально существовавшие в Средние века наказания отличались устрашающим разнообразием: ордалии и казни были во многом более изощренными, чем изображенные в романе (например, у преступников сначала вживую вырезали внутренности, а потом их обезглавливали, женщин просто сжигали), сходные наказания мужчин и женщин различались по форме осуществления, например, такие как применение позорного столба и позорного стула [Хатунов, 2010, с. 172-176; Хатунов, 2003, с. 323; Винокурова, 2016, с. 110-126]. Реалистическими иллюстрациями подобных казней были заполнены книги (видимо, в воспитательных целях), многие старинные иллюстрации выложены сейчас в Интернете. Таким образом, Дж. Мартин берет выборочно элементы суда и правосудия из Средневековья, вплетая их в повествование. Мир, где идет «война всех против всех», это мир усредненного Средневековья из разных периодов, игра наслоений разных правовых институтов, опосредованная фантазией автора. Изображаемое, как представляется, интересно ему не само по себе и даже не как арена борьбы за власть, а как способ вскрыть, увидеть и показать зрителю то, что находится под тонким слоем современной цивилизованности и культуры, в том числе правовой. Более того, фантазия Мартина при изображении суда и правосудия не охватывает такие изощренные и «креативные» формы, как коллективная уголовная ответственность (сохранившаяся, например, в Северной Корее).

\section{Роман Дюс.Р.Р. Мартина как культурно-просветительский проект о средневековом суде и правосудии}

Роман с его аллюзиями к Средневековью, которые поддерживает и переосмысливает автор, безусловно привлекает внимание читателей к самому феномену Средневековья, из которого Европа вышла сравнительно недавно, как к прошлому, которое надо знать и логику которого надо понимать. Применяемые Мартином приемы фэнтези, образности впитывают достижения медиевистики и демонстрируют 
достаточно высокий уровень ознакомления с ними. Так, в массовую культуру входят приемы, средства и техника медиевистики, которая научно анализирует и реконструирует реальные события прошлого, а в романе это сделано художественным образом.

Раньше история и события Средневековья вызывали академический интерес, но благодаря работам Толкиена, Ле Гуин, Мартина и других представителей жанра фэнтези, она стала объектом пристального интереса массовой культуры [Kyrchanoff, 2018, p. 19] и из занятия академических исследователей-интеллектуалов превратилась в составную часть современного массового сознания. Произведения в стиле фэнтези являются пусть и не прямыми, а косвенными посредниками этого перехода, который обладает всеми признаками постмодернистского перехода от простого следования за фактами и их анализа с точки зрения просвещения, поиска истины и других классических задач науки к конструированию множественности возможных сценариев последовательности событий. Такое конструирование осуществляется не в целях утверждения одной истины, одной справедливости, одного линейного прогресса, а в целях утверждения многозначной, амбивалентной, множественной критической оценки явлений. Не одна истина, а несколько, не одно правосудие, а множество, вот постмодернистская квинтэссенция фэнтези Мартина.

Для современного человека под влиянием кино, телевидения и Интернета, создающих иллюзию достоверности вымысла писателя, герои особенно популярных произведений становятся практически такими же реальными, как живые люди, а знание происходивших с ними событий - частью современного культурного кода. Многие образы и события из фэнтези рассматриваются фанатами как часть реальности. Как справедливо отметил однажды писатель Анджей Сапковский, существует категория людей, которые не знают имени отца Зевса, но знают имя отца короля Артура, а также таких персонажей как Мерлин [Сапковский, 1999, с. 214]. Показателем прорастания образов и фактов фэнтези в культуру современной повседневности может служить и опрос американцев о наиболее шокирующих и впечатляющих событиях истории Америки XX в., в котором на первом месте значится убийство Дж. Кеннеди, а на втором - то, что отцом Люка Скайуокера оказался Дарт Вейдер [Петрова, 2019, с. 7].

Не избежал этого и роман Дж. Мартина. Многие тысячи поклонников автора «проживают» жизнь его персонажей в книгах и фильмах, обсуждают их на форумах, предлагая свои варианты развития событий, в том числе и относящихся к суду и правосудию, пыта- 
ются вникнуть в особенности средневековых отношений и, возможно, впервые начинают воспринимать Средневековье как реальное прошлое, а его институты как реально применявшиеся. Показательно в этом смысле обсуждение ситуации с казнью Неда Старка, который не использовал право судебного поединка. Часть фанатов вполне серьезно стала обсуждать, почему ему не было дано право поединка ${ }^{1}$. Обсуждение этого эпизода и самой возможности поединка фанатами показывает, с одной стороны, что современный читатель (и зритель), даже имея дело с произведением, написанным с опорой на средневековую логику и понимание справедливости той эпохи, к тому же воссозданными в духе и внутренней логике самого фантазийного произведения, тем не менее оценивает происходящее через призму современного понимания справедливости. Такое понимание включает в себя равное ко всем отношение в судебном процессе и другие современные принципы, неизвестные Средневековью - как реальному, так и «усредненному», созданному Дж.Р.Р. Мартином, который, кстати, сверяется со своей придуманной в логике романа справедливостью. Об этой особенности восприятия романа фанатами, собственно, свидетельствует сама постановка вопроса о том, почему другие герои могли воспользоваться данной процедурой доказательства невиновности, а этот герой - нет. С другой стороны, активная вовлеченность фанатов в дискуссию об этой возможности свидетельствует о возникшем на основе романа интересе и импульсе к осмыслению такого своеобразного явления как судебный поединок как части, пусть и фантазийной, но порождающей аллюзию со средневековым институтом реальности. Это означает оживление исторической и культурной памяти у новых поколений, когда история перестает быть только частью учебников и монографий и становится частью жизни. Важно, чтобы после этого фанаты обращались к научным историческим исследованиям и проникались интересом к реальной истории, обогащая свое знание истории и культуры, в том числе эволюции суда и правосудия.

Некоторые юристы используют романы Дж. Мартина, для того чтобы привлечь внимание научного сообщества к возможностям правового инструментария для расширения вариативности интерпретации (толкования) правовых актов, в том числе для использования в учеб-

${ }^{1}$ Атмакин А. Игра престолов. Почему Нед Старк не потребовал суда поединком и просто позволил отсечь себе голову? Форум. - URL: https://yandex.ru/q/question/igra prestolov_pochemu_ned_stark_ne_suda_fe7c24a9/ (дата обращения 20.02.2021). 
ном процессе. Так, венгерский автор 3. Кёртвееши проводит детальный юридический анализ клятвы Ночного дозора и открывающихся в связи с ее принесением возможностей на основе логики различных видов толкований правоотношений авторитетными учеными-юристами и даже Верховным судом США [Körtvélyesi, 2019, p. 1-24].

Не менее показательны в культурологическом плане сообщения об использовании риторики и институтов романа в современных судебных процессах, даже адвокатами (т.е. профессиональными юристами) ${ }^{1}$, попытках добиться испытания поединком, причем даже на мечах $^{2}$.

\section{Заключение}

Анализ мегаэпопеи Дж. Мартина «Песнь льда и огня» показывает, что, несмотря на мозаичность и фрагментарность изображения картины суда и правосудия, автором достаточно четко выражена главная задача данных институтов - выступать в качестве инструмента, причем далеко не основного, борьбы за власть в Вестеросе. Такое понимание роли суда и правосудия находится в очевидном противоречии с современной трактовкой роли суда как института защиты и восстановления нарушенных прав человека. С помощью приемов, свойственных жанру фэнтези, роман стимулирует читателя к осмыслению и более вдумчивому и критическому отношению к стереотипам о средневековом и современном праве. Тем самым в массовую культуру вносятся элементы научного знания, в том числе об истории права.

\section{Список литературы}

Абакумова И.А. Искусственные языки вымышленного мира Джорджа Мартина // Филологические науки. Вопросы теории и практики. - Тамбов, 2016. - № 12-1(66). C. $12-14$.

${ }^{1}$ Hooton Ch. Lawyer requests 'trial by combat' in real-life Game of Thrones. Attorney called for the trial to take place 'personally and or by way of a champion'. Comments, 08 August 2015. URL : https://www.independent.co.uk/arts-entertainment/tv/news/real-lifegame-thrones-lawyer-has-requested-trail-combat-10445751.html (accessed 20.02.2021)

2 Дуэль на мечах как способ разрешить бракоразводный процесс. - 2020. 17 января. - URL : https://pravo.ru/news/217613/ (дата обращения 20.02.2021). 
Аванесян А.А. Образ Средневековья в сериале «Игра престолов»: проблема достоверности // Вестник ТвГУ. Серия «История». - Тверь, 2019. - № 3 (51). - С. 74-87.

Винокурова М.В. Обвинение, оправдание, наказание в обычном праве малых городов Средневековой Англии // Новое прошлое. - Ростов-на-Дону, 2016. - № 3. C. 110-126.

Глянцев A. Математики раскрыли секрет популярности «Игры престолов». 2020. - 03.11. - URL: https://www.vesti.ru/nauka/article/2480609 (дата обращения: 1.02.2021)

Демочкина А.С., Михеева Е.Н., Кузнецова С.В. Особенности фонетики вымышленных языков (на примере дотракийского и валирийского языков) как способ видения «возможных миров» в произведении Джорджа Мартина «Песнь льда и пламени» // VIII Авдеевские чтения : Сборник статей по материалам Всероссийской научнопрактической конференции. Пенза, 22 апреля 2020 г. - Пенза, 2020. - С. 151-154.

Заботин С.Ю. Отражение культурных конфликтов в «Песни льда и огня» Джорджа Р.Р. Мартина // Молодежный вестник СПбГИК. - СПб., 2019. - № 2 (12). С. 119-122.

Иванченко A.E. Исторические параллели в «Песни льда и пламени» // Развитие и актуальные вопросы современной науки. - Магнитогорск, 2017. - № 1. - С. $22-24$.

Исаев И.А. Цифровая магия власти: первая управленческая революция // LexRussica. - M., 2019. - № 5 (150). - С. 9-29.

Кардакова Д.О. Авторские неологизмы в «Игре престолов» Джорджа Р.Р. Мартина // Форум молодых ученых. - Саратов, 2018. - № 5-2 (21). - С. 9093.

Косарев Д.В. Грамматические категории имени существительного в искусственных языках вселенной «Льда и пламени» // Языкознание: Материалы 57-й Международной научной студенческой конференции. Новосибирск, 14-19 апреля 2019 г. Новосибирск, 2019. - С. 12-13.

Круглый стол по «Игре престолов» в редакции гефтер. ру // Игра престолов: прочтение смыслов. Историки и психологи исследуют мир Джорджа Мартина. - М. : ACT, 2019. - С. 219-271.

Кучеренко П.А. Роль и место неотъемлемых и подразумеваемых полномочий президента в конституционно-правовой системе Соединенных Штатов Америки // Вестник Российского университета дружбы народов. Серия «Юридические науки». М., 2010. - № 3. - С. 55-65.

Мартин Дж. Р.Р. Пламя и кровь. Кровь драконов. - М. : АСТ, 2018 а. - 384 с.

Мартин Дж. Р.Р. Игра престолов: Из цикла «Песнь льда и огня». - М. : АСТ, 2018 б. -770 [14] с.

Мартин Дж. Р.Р. Битва королей: Из цикла «Песнь льда и огня». - М. : АСТ, 2019 a. - 776 [8] c.

Мартин Джс. Р.Р. Буря мечей. Пир стервятников. - М. : АСТ, 2019 б. - 1728 [2] с. 
Мартин Дж. Р.P. Танец с драконами. Грезы и пыль. - М. : АСТ, 2019 в. - 539 [5] с. Мкртчан Т.Ю. Структурные особенности авторских топонимов в цикле эпических фэнтези-романов Дж.Р.Р. Мартина «Песнь льда и пламени» // Филологические науки. Вопросы теории и практики. - Тамбов, 2016. - № 10-3 (64). - С. 127-129.

Сапковский А. Мир короля Артура // Дорога без возврата. - М. : АСТ, 1999. C. 214-391.

Солдаткина Я. «Джоново царство»: христианские образы в мире «Игры престолов» // Игра престолов: прочтение смыслов. Историки и психологи исследуют мир Джорджа Мартина. - М. : АСТ, 2019. - С. 195-218.

Стрижаков И.В. Королевский суд справедливости в Англии XVI-XVII вв. // Правоприменение. - Омск, 2017. - Т. 1, № 2. - С. 38-45.

Петрова Ю. Предисловие. Ничего ты не знаешь, Джон Сноу // Игра престолов: прочтение смыслов. Историки и психологи исследуют мир Джорджа Мартина. M. : ACT, 2019. - C. 7-8.

Праздников А.Г. Государственные изменники периода Войны роз: социальная среда и мотивация // Средние века. - М., 2011. - Т. 72, № 1/2. - С. 153-174.

Томилина Е.А. Концепт «власть» в цикле «Песнь льда и пламени» Дж. Мартина // Русский мир: динамика научного познания : сборник статей участников Международной научно-практической конференции / ответственный редактор С.В. Напалков, научный редактор Е.В. Валеева; Арзамасский филиал федерального государственного автономного образовательного учреждения высшего образования «Национальный исследовательский Нижегородский государственный университет им. Н.И. Лобачевского», Фонд «Русский мир». - Арзамас, 2019. - С. 461-465.

Фомина Е.В. Война роз из прошлого сквозь современность // Современные тенденции развития науки и технологий. - 2016. - № 4/5. - С. 97-100.

Хатунов С.Ю. Позорный столб и позорный стул как уголовное наказание в средневековой Англии // Ленинградский юридический журнал. - СПб., 2010. - № 4 (22). - C. 172-176.

Хатунов С.Ю. Преступление и наказание в средневековой Англии (англосаксонский, англо-нормандский, анжуйский периоды). - М. : Компания Спутник +, 2003. -323 c.

Штейнман М. Добро и зло в «Игре престолов» // Игра престолов: прочтение смыслов. Историки и психологи исследуют мир Джорджа Мартина. - М. : АСТ, 2019 a. - C. 149-172.

Штейнман М.А. Трансформация метафоры власти в XX - начале XXI столетия (на примере произведений Дж.Р.Р. Толкина и Дж. Мартина // Полития: Анализ. Хроника. Прогноз (Журнал политической философии и социологии политики). - М., 2019 б. - № 2 (93). - С. 28-47. 
Шляхтин Р. Степь и ее люди. Дотракийское море и дотракийцы в «Песне льда и пламени» // Игра престолов: прочтение смыслов. Историки и психологи исследуют мир Джорджа Мартина. - М. : АСТ, 2019. - С. 119-134.

Körtvélyesi Z. Game of Norms: Law, Interpretation, and the Realms in Game of Thrones. - Budapest : Magyar Tudományos Akadémia/Hungarian Academy of Sciences, 2019. - P. 1-24. - (MTA Law Working Papers; N 3).

Kyrchanoff M.W. Historical grand narratives of the seven kingdoms of Westeros: from invention to deconstruction of a traditional medieval historiography // Journal of Frontier Studies. - Astrakhan, 2018. - N 1 (9). - C. 17-46.

Rohani S.I., Abootalebi H. Mending Wall: A Study of Restorative Justice in George R.R. Martin's A Song of Ice and Fire and Tales of Dunk and Egg // k@ta: a biannual publication on the study of language and literature. - Surabaya (Indonesia), 2015. Vol. 17, N 2. - P. 58-63. - DOI: 10.9744/kata. 17.2.58-63.

\section{References}

Abakumova, I.A. (2016). Iskusstvennye jazyki vymyshlennogo mira Dzhordzha Martina [Artificial languages of the fictional world of George Martin]. In Filologicheskie nauki. Voprosy teorii i praktiki [Philological Sciences. Questions of theory and practice], (12-1(66)), (pp. 12-14). Tambov. (In Russian).

Avanesjan, A.A. (2019). Obraz Srednevekov'ja v seriale «Igra prestolov»: problema dostovernosti [The image of the Middle Ages in the TV series «Game of Thrones»: the problem of authenticity]. In Vestnik TvGU. Serija «Istorija» [Herald of Tver State University. Series «History»]. (3 (51)), (pp. 74-87). Tver'. (In Russian).

Vinokurova, M.V. (2016). Obvinenie, opravdanie, nakazanie v obychnom prave malyh gorodov Srednevekovoj Anglii [Accusation, justification, punishment in the Common Law of Small Towns in Medieval England]. In Novoe proshloe [New Past], (3), (pp. 110126). Rostov-on-Don. (In Russian).

Glyancev, A. (2020). Matematiki raskryli sekret populyarnosti «Igry prestolov». [Glyantsev A. Mathematicians revealed the secret of the popularity of «Game of Thrones»]. Retrieved from URL: https://www.vesti.ru/nauka/article/2480609 (In Russian).

Demochkina, A.S., Miheeva, E.N., Kuznecova, S.V. (2020). Osobennosti fonetiki vymyshlennyh jazykov (na primere dotrakijskogo i valirijskogo jazykov) kak sposob videnija «vozmozhnyh mirov» v proizvedenii Dzhordzha Martina «Pesn' l'da i plameni» [Features of phonetics of fictional languages (on the example of Dothraki and Valyrian languages) as a way of seeing «possible worlds» in the work of George Martin «A Song of Ice and Fire»]. In VIII Avdeevskie chtenija. Sbornik statej po materialam Vserossijskoj nauchnoprakticheskoj konferencii. Penza, 22 aprelja $2020 \mathrm{~g}$. [VIII Avdeev Readings. Collection of articles based on the materials of the All-Russian Scientific and Practical Conference. Penza, April 22, 2020], 151-154. Penza. (In Russian). 
Zabotin, S. Ju. (2019). Otrazhenie kul'turnyh konfliktov v «Pesni l'da i ognja» Dzhordzha R.R. Martina [A reflection of the cultural conflicts in «a Song of ice and fire» by George R.R. Martin]. In Molodezhnyj vestnik SPbGIK [Youth Bulletin SPbGIK]. (2 (12)), (pp. 119-122). Saint Petersburg. (In Russian).

Ivanchenko, A.E. (2017). Istoricheskie paralleli v «Pesni l'da i plameni» [Historical parallels in «Songs of Ice and Fire»]. In Razvitie i aktual'nye voprosy sovremennoj nauki [Development and current issues of modern science], (1), (pp. 22-240. Magnitogorsk. (In Russian).

Isaev, I.A. (2019). Cifrovaja magija vlasti: pervaja upravlencheskaja revoljucija [Digital Magic of Power: The First Managerial Revolution]. In Lex Russica, (5 (150)), (pp. 9-29). Moscow. (In Russian).

Kardakova, D.O. (2018). Avtorskie neologizmy v «Igre prestolov» Dzhordzha R.R. Martina [Author's neologisms in the «Game of Thrones» by George R.R. Martin]. In Forum molodyh uchenyh [Forum of Young Scientists], (5-2 (21)), (pp. 90-93). Saratov. (In Russian).

Kosarev, D.V. (2019). Grammaticheskie kategorii imeni sushhestvitel'nogo v iskusstvennyh jazykah vselennoj «L'da i plameni» [Grammatical categories of the noun in the artificial languages of the universe of «Ice and Fire»]. In Jazykoznanie. Materialy 57-j Mezhdunarodnoj nauchnoj studencheskoj konferencii. Novosibirsk, 14-19 aprelja $2019 \mathrm{~g}$. [Linguistics. Materials of the 57 th International Scientific Student Conference. Novosibirsk, April 14-19, 2019], 12-13. Novosibirsk. (In Russian).

(Anonymous) (2019). Kruglyj stol po «Igre prestolov» v redakcii gefter.ru [Round table on the "Game of Thrones» in the editorial office of gefter.ru]. In Igra prestolov: prochtenie smyslov. Istoriki $i$ psihologi issledujut mir Dzhordzha Martina [Game of Thrones: Reading the meanings. Historians and psychologists explore the world of George Martin], 219-271. Moscow : AST. (In Russian).

Kucherenko, P.A. (2010). Rol' i mesto neot'emlemyh i podrazumevaemyh polnomochij prezidenta v konstitucionno-pravovoj sisteme Soedinennyh Shtatov Ameriki [The role and place of the inherent and implied powers of the President in the constitutional and legal system of the United States of America]. In Vestnik Rossijskogo universiteta druzhby narodov. Serija «Juridicheskie nauki» [Bulletin of the Peoples ' Friendship University of Russia. A series of «Legal science»], (3), (pp. 55-65). Moscow. (In Russian).

Martin, Dzh. R.R. (2018 a). Plamja i krov'. Krov' drakonov [Fire and blood. The blood of dragons]. Moscow : AST. (In Russian).

Martin, Dzh. R.R. (2018 b). Igra prestolov: Iz cikla «Pesn' l'da i ognja» [Game of Thrones: A Song of Ice and Fire]. Moscow : AST. (In Russian).

Martin, Dzh. R.R. (2019 a). Bitva korolej: Iz cikla «Pesn' l'da i ognja» [Battle of the Kings: From the series «A Song of Ice and Fire»]. Moscow : AST. (In Russian).

Martin, Dzh. R.R. (2019 b). Burja mechej. Pir stervjatnikov [A storm of swords. A feast of vultures]. Moscow: AST. (In Russian). 
Martin, Dzh. R.R. (2019 v). Tanec s drakonami. Grezy i pyl' [Dance with dragons. Dreams and dust]. Moscow : AST. (In Russian).

Mkrtchan, T. Ju. (2016). Strukturnye osobennosti avtorskih toponimov v cikle jepicheskih fjentezi-romanov Dzh. R.R. Martina «Pesn' l'da i plameni» [Structural features of the author's toponyms in the cycle of epic fantasy novels by J.R. R. Martin «A Song of Ice and Fire»]. In Filologicheskie nauki. Voprosy teorii i praktiki [Philological Sciences. Questions of theory and practice], (10-3 (64)), (pp. 127-129). Tambov. (In Russian).

Sapkovskij, A. (1999). Mir korolja Artura [King Arthur's World]. In Doroga bez vozvrata [The road of no return], 214-391. -Moscow : AST. (In Russian).

Soldatkina, Ja. (2019). «Dzhonovo carstvo»: hristianskie obrazy v mire «Igry prestolov» [«John's Kingdom»: Christian images in the world of «Game of Thrones»]. In Igra prestolov: prochtenie smyslov. Istoriki i psihologi issledujut mir Dzhordzha Martina [Game of Thrones: Reading the Meanings. Historians and psychologists explore the world of George Martin], 195-218. Moscow : AST. (In Russian).

Strizhakov, I.V. (2017). Korolevskij sud spravedlivosti v Anglii XVI-XVII vv. [The Royal Court of Justice in England of the XVI-XVII centuries]. In Pravoprimenenie [Law enforcement], T. 1, (2), (pp. 38-45). Omsk. (In Russian).

Petrova, Ju. (2019). Predislovie. Nichego ty ne znaesh' Dzhon Snou [Preface. You Don't Know Anything Jon Snow]. In Igra prestolov: prochtenie smyslov. Istoriki i psihologi issledujut mir Dzhordzha Martina [Game of Thrones: Reading the Meanings. Historians and psychologists explore the world of George Martin], 7-8. Moscow : AST. (In Russian).

Prazdnikov, A.G. (2011). Gosudarstvennye izmenniki perioda vojny roz: social'naja sreda i motivacija [State traitors of the War of the Roses: social environment and motivation]. In Srednie veka [The Middle Ages], T. 72, (1-2), (pp. 153-174). Moscow. (In Russian).

Tomilina, E.A. (2019). Koncept «vlast'» v cikle «Pesn' l'da i plameni» Dzh. Martina [The concept of «power» in the cycle «Song of Ice and Fire» by J. Martin]. In Russkij mir: dinamika nauchnogo poznanija. Sbornik statej uchastnikov Mezhdunarodnoj nauchnoprakticheskoj konferencii. Otvetstvennyj redaktor S.V. Napalkov, nauchnyj redaktor E.V. Valeeva; Arzamasskij filial federal'nogo gosudarstvennogo avtonomnogo obrazovatel'nogo uchrezhdenija vysshego obrazovanija "Nacional'nyj issledovatel'skij Nizhegorodskij gosudarstvennyj universitet im. N.I. Lobachevskogo», Fond «Russkij mir» [Russian World: dynamics of scientific knowledge. Collection of articles by participants of the International Scientific and Practical Conference. Executive editor S.V. Napalkov, Scientific Editor E.V. Valeeva; Arzamas Branch of the Federal State Autonomous Educational Institution of Higher Education «Lobachevsky National Research Nizhny Novgorod State University», Russian World Foundation], 461-465. Arzamas. (In Russian).

Fomina, E.V. (2016). Vojna roz iz proshlogo skvoz' sovremennost' [The War of Roses from the past through modernity]. In Sovremennye tendencii razvitija nauki $i$ 
tehnologij [Modern trends in the development of science and technology], (4-5), (pp. 97100). (In Russian).

Hatunov, S. Ju. (2010). Pozornyj stolb i pozornyj stul kak ugolovnoe nakazanie v srednevekovoj Anglii [Shameful post and shameful chair as a criminal punishment in medieval England]. In Leningradskij juridicheskij zhurnal [Leningrad Law Journal]. (4 (22)), (pp. 172-176). Saint Petersburg. (In Russian).

Hatunov S. Ju. (2003). Prestuplenie i nakazanie v srednevekovoj Anglii (anglosaksonskij, anglo-normandskij,anzhujskij periody) [Crime and punishment in Medieval England (Anglo-Saxon, Anglo-Norman, and Angevin periods)]. Moscow : Kompanija Sputnik +. (In Russian).

Shtejnman, M. (2019 a). Dobro i zlo v «Igre prestolov» [Good and Evil in the «Game of Thrones»]. In Igra prestolov: prochtenie smyslov. Istoriki i psihologi issledujut mir Dzhordzha Martina [Game of Thrones: Reading the Meanings. Historians and psychologists explore the world of George Martin], 149-172. Moscow : AST. (In Russian).

Shtejnman, M.A. (2019 b) Transformacija metafory vlasti v XX - nachale XXI stoletija (na primere proizvedenij Dzh. R.R. Tolkina i Dzh. Martina [Transformation of the Metaphor of Power in the XX-beginning of the XXI century (on the example of the works of J.R. R. Tolkien and J. Martin]. In Politija: Analiz. Hronika. Prognoz (Zhurnal politicheskoj filosofii i sociologii politiki) [Politiya: Analiz. The chronicle. Prognoz (Journal of Political Philosophy and Sociology of Politics), (2 (93)), (pp. 28-47). Moscow. (In Russian).

Shljahtin, R. (2019). Step' i ee ljudi.Dotrakijskoe more i dotrakijcy v «Pesne l'da i plameni» [The steppe and its people. The Dothraki Sea and the Dothraki people in the Song of Ice and Fire]. In Igra prestolov: prochtenie smyslov. Istoriki i psihologi issledujut mir Dzhordzha Martina [Game of Thrones: Reading the Meanings. Historians and psychologists explore the world of George Martin], 119-134. Moscow : AST. (In Russian).

Körtvélyesi, Z. (2019). Game of Norms: Law, Interpretation, and the Realms in Game of Thrones. In MTA Law Working Papers Budapest: Magyar Tudományos Akadémia / Hungarian Academy of Sciences, (3), (pp. 1-24). Budapest. (In English).

Kyrchanoff, M.W. (2018). Historical grand narratives of the seven kingdoms of Westeros: from invention to deconstruction of a traditional medieval historiography. In Journal of Frontier Studies, (1 (9)), (pp. 17-46). Astrakhan. (In English).

Rohani, S. 1, Abootalebi, H. (2015). Mending Wall: A Study of Restorative Justice in George R.R. Martin's A Song of Ice and Fire and Tales of Dunk and Egg. In k@ta: $a$ biannual publication on the study of language and literature. Vol. 17, (2), (pp. 58-63). Surabaya (Indonesia), DOI: 10.9744/kata. 17.2.58-63 